Journal of Extension Education

Vol. 28 No. 4, 2016

DOI:https://doi.org/10.26725/JEE.2016.4.28.5727-5734

\title{
Understanding Learning Style Variations among Undergraduate Students
}

\section{N. Jayakumar ${ }^{1}$, Anu Suresh ${ }^{2}$, M.Sundaramari ${ }^{3}$ and D.Puthira Prathap ${ }^{4}$}

\begin{abstract}
A study was conducted in Vellore district of Tamil Nadu state to understand the learning styles of students. The term learning style refers to the way or method or approach by which a student learns. The study explored the possible learning style variations among agricultural, horticultural, engineering and arts \& science students and their association with academic achievement. One hundred and twelve students were randomly selected from the four streams and their learning styles were analyzed. In the agricultural and horticultural streams, a majority of the students were auditory learners. They were also found to be predominantly unimodal learners. Overall, it was found that majority of the students were visual learners followed by auditory and kinesthetic style. The highest percentage of kinesthetic learners was found among engineering students. Trimodal learners scored the highest mean percentage of marks. The influence of learning styles on the academic achievements of the students did not show a significant relationship.
\end{abstract}

Keywords : Learning styles, Visual learners, Auditory learners, Kinesthetic learners, Undergraduate students, Academic achievement, India

\section{INTRODUCTION}

Students have different levels of motivation, different attitudes about teaching and learning and different responses to specific classroom environments and instructional practices. The more thoroughly instructors understand the differences, the better chance they have of meeting the diverse learning needs of all of their students (Felder \& Brent, 2005).

Students learn in many ways - by seeing and hearing; reflecting and acting; reasoning logically and intuitively;

1. Assistant Professor, Adhiparasakthi Agricultural College, G.B.Nagar, Kalavai, Vellore district -632506 2. PG Scholar, Sam Higginbottom University of Agriculture, Technology and Sciences, Allahabad, Uttar Pradesh - 211007 3. Professor (Agricultural Extension), Faculty of Agriculture and Animal Husbandry, Gandhigram Rural Institute, Gandhigram - 624302 and 4. Principal Scientist (Agricultural Extension), ICAR-Sugarcane Breeding Institute, Coimbatore - 641007 
memorizing and visualizing and drawing analogies.The term learning style refers to the way or method or approach by which a student learns. Learning styles are "characteristic cognitive, affective, and psychological behaviors that serve as relatively stable indicators of how learners perceive, interact with, and respond to the learning environment" (Keefe,1979). The problem is that no two students are alike. They have different backgrounds, strengths and weaknesses, interests, ambitions, senses of responsibility, levels of motivation, and approaches to studying. Teaching methods also vary. Some instructors mainly lecture, while others spend more time on demonstrations or activities; some focus on principles and others on applications; some emphasize memory and others understanding. How much a given student learns in a class is governed not only by student's native ability and prior preparation but also by the compatibility of the student's attributes as a learner and the instructor's teaching style (Felder \& Brent, 2005).

Diagnosing and interpreting learning styles provide data as to how individuals perceive, interact with and respond to the learning environment. According to Cronbach and Snow(1977), learning styles could be used to predict what kind of instructional strategies or methods would be most effective for a given individual and learning task. Effective learning will take place if prior analysis of learning preference of the learners is done and instructions are designed accordingly (Pashler et al., 2008).

In specialized fields such as agricultural education, for learning to be successful, the teaching style of the instructors should complement the students' learning style. However, the general feeling is that many teachers do not realize that in the class room, students differ among themselves in the way they process and comprehend information. The professional courses like agriculture, horticulture and engineering are considered to be more practical oriented differing from arts \& science courses. Hence, it is assumed that the learning styles requirements of the students need to vary as per the requirement of the courses.

The present study was taken up to understand the learning style of students and to relate it to their academic achievement. The following were the objectives:

- To study the learning styles of the undergraduate students.

- To analyze the relationship between academic achievement and learning styles of the undergraduate students.

\section{METHODOLOGY}

The study was conducted in Adhiparasakthi Educational Institution located in Vellore district of Tamil Nadu. 
The institution offers undergraduate programmes in Agriculture, Horticulture, Biochemistry, Microbiology, Mathematics, Computer Science, Computer Application, Commerce, Business Administration and Engineering programmes. Stratified Random Sampling technique was used to select 112 respondents from the four streams, belonging to four colleges of Adhiparasakthi Educational Institution viz., Agriculture stream (18 students) - Adhiparasakthi Agricultural College (APAC), Horticulture stream (8 students) - Adhiparasakthi Horticultural College (APHC), Engineering stream (51 students) - Adhiparasakthi Engineering College (APEC) and Arts \& Science stream (35 students) - Adhiparasakthi Arts \& Science College (APCAS). The learning styles were analyzed using VAK learning style model (Barbe et al,1979).

\section{The VAK Learning Style model}

The VAK learning styles model (Barbe et.al, 1979) provides a simple way to explain and understand learning styles. The VAK learning style uses the three main sensory receivers (Vision, Auditory and Kinesthetic) to determine a person's dominant or preferred learning style. These three styles are as follows:

\section{Visual Learning Style}

They have preference for seen or observed things, including pictures, diagrams, demonstrations, displays, handouts, films, flip chart etc. These people will be best able to perform a new task after reading the instructions or watching someone else does it first. These are the people who will work from lists and written directions and instructions.

\section{Auditory Learning Style}

They have preference for the transfer of information through listening: to the spoken word, of self or others, of sounds and noises. These people will be best able to perform a new task after listening to instructions from an expert. These are the people who are happy being given spoken instructions over the telephone, and can remember all the words to songs that they hear.

\section{Kinesthetic Learning Style}

They have preference for physical experience - touching, feeling, holding, and doing practical hands-on experiences. These people will be best able to perform a new task by going ahead and trying it out, learning as they go.

No one possesses exclusively one single style or preference. Learners use all three methods to receive information. However, one or more of these receiving styles is normally dominant.

For the purpose of studying the learning style by this method, the questionnaire developed by Swinburne University of Technology, was utilized. The questionnaire contains 30 questions with three options in each. The option "A" is related to the visual style of learning. The option " $\mathrm{B}$ " is related to the auditory style of learning and option " $\mathrm{C}$ " is related to the kinesthetic style of learning. 
Based on the total score obtained by the respondent in each category, he/she may be classified to have a visual, auditory or kinesthetic style of learning.

Academic achievement can be defined as the extent to which a learner is profiting from instructions in a given area of learning i.e., achievement is reflected by the extent to which skill or knowledge has been imparted to him. In our society academic achievement is considered as a key criterion to judge one's total potentiality and capability. Academic achievement has become an index of student's future in this highly competitive world.Hence academic achievement occupies a very important place in education as well as in the learning process. The academic achievement is measured by means of marks / grade point average obtained by the student. Since the different streams had different grading systems, the academic achievement was calculated as the percentage of marks obtained by the student before administering this test (Jayakumar \& Surudhi, 2015).

\section{FINDINGS AND DISCUSSION}

The results of the study revealed that majority of the students were visual learners (52.69\%). These learners need to see the teacher's body language and facial expression to fully understand the content of a lesson. They prefer sitting at the front of the classroom. They remember best what they see: pictures, diagrams, flow charts, time lines, films, demonstrations. If something is simply said to them they will probably forget it.

The next highest percentage was the auditory learners (32.14\%). They learn best through verbal lessons, discussions, talking things through and listening to what others have to say. These learners often benefit from reading text loud and using a tape recorder.

Kinesthetic learners were just 8.03 per cent. They learn best through a hands on approach, actively exploring the physical world around them. They may find it hard to sit still for long periods and may become distracted by their need for activity and exploration.

Few of the students also exhibited a combination of these styles, but were fewer in number. The combination of visual and auditory (3.57\%) was followed by a combination of visual, auditory and kinesthetic which was found to be 1.79 per cent.

The stream - wise distribution of the students (Table 1) showed that the highest percentage (66.66\%) of visual learners were found in engineering stream followed by arts and science stream (51.43\%). Only 38.89 per cent of the students were Visual learners in agriculture stream.

A majority of the students were auditory learners in the horticultural and agricultural streams with 62.50 per cent and 61.11 per cent respectively. The results also reveal that agricultural 
students are unimodal learners (students who indicated only one option for each question administered).

In the case of horticultural stream, no visual learners or kinesthetic learners could be identified. Bimodal (V + A) learners constituted 12.5 per cent and trimodal learners $(\mathrm{V}+\mathrm{A}+\mathrm{K})$ constituted 25 per cent, though the majority were unimodal learners $(62.50 \%)$.

It could be seen from the table that majority of students in agricultural and horticultural stream were auditory learners. The findings therefore reveal that these students would remember much of what they hear. They get a lot out of discussion, prefer verbal explanation to visual demonstration, and learn effectively by explaining things to others.

It could also be inferred that teaching methods such as lectures, audio books and group discussions, therefore, cannot be done away with and has to be an integral part of the instructional methodology, for the students of agricultural and horticultural learners. Kinesthetic learners were not reported from both agricultural and horticultural streams. The results are contrary to the general feeling that agricultural and horticultural students would prefer a kinesthetic learning style as the curricula of these two streams have a significant space allotted for practical and field applications.

Table 1.

Stream - wise Distribution of Students Based on VAK Learning Style

\begin{tabular}{|c|c|c|c|c|c|c|c|c|}
\hline \multirow[b]{2}{*}{$\begin{array}{l}\text { S1. } \\
\text { No. }\end{array}$} & \multirow[b]{2}{*}{ Stream } & \multicolumn{7}{|c|}{ Learning style } \\
\hline & & $\begin{array}{l}\text { Visual } \\
\text { (V) }\end{array}$ & $\begin{array}{c}\text { Auditory } \\
\text { (A) }\end{array}$ & $\begin{array}{c}\text { Kinesthetic } \\
\text { (K) }\end{array}$ & $\mathbf{V}+\mathbf{A}$ & $\mathbf{V}+\mathbf{K}$ & $\mathbf{A}+\mathbf{K}$ & $\mathbf{V}+\mathbf{A}+\mathbf{K}$ \\
\hline 1. & Agriculture & $\begin{array}{c}7 \\
(38.89 \%)\end{array}$ & $\begin{array}{c}11 \\
(61.11 \%)\end{array}$ & -- & -- & -- & -- & -- \\
\hline 2. & Horticulture & -- & $\begin{array}{c}5 \\
(62.50 \%)\end{array}$ & -- & $\begin{array}{c}1 \\
(12.5 \%)\end{array}$ & -- & -- & $\begin{array}{c}2 \\
(25 \%)\end{array}$ \\
\hline 3. & Engineering & $\begin{array}{c}34 \\
(66.66 \%)\end{array}$ & $\begin{array}{c}7 \\
(13.73 \%)\end{array}$ & $\begin{array}{c}7 \\
(13.73 \%)\end{array}$ & $\begin{array}{c}1 \\
(1.96 \%)\end{array}$ & $\begin{array}{c}1 \\
(1.96 \%)\end{array}$ & $\begin{array}{c}1 \\
(1.96 \%)\end{array}$ & -- \\
\hline 4. & $\begin{array}{l}\text { Arts \& } \\
\text { Science }\end{array}$ & $\begin{array}{c}18 \\
(51.43 \%)\end{array}$ & $\begin{array}{c}13 \\
(37.14 \%)\end{array}$ & $\begin{array}{c}2 \\
(5.71 \%)\end{array}$ & $\begin{array}{c}2 \\
(5.71 \%)\end{array}$ & -- & -- & -- \\
\hline & Total & $\begin{array}{c}59 \\
(52.69 \%)\end{array}$ & $\begin{array}{c}36 \\
(32.14 \%)\end{array}$ & $\begin{array}{c}9 \\
(8.03 \%)\end{array}$ & $\begin{array}{c}4 \\
(3.57 \%)\end{array}$ & $\begin{array}{c}1 \\
(0.89 \%)\end{array}$ & $\begin{array}{c}1 \\
(0.89 \%)\end{array}$ & $\begin{array}{c}2 \\
(1.79 \%)\end{array}$ \\
\hline
\end{tabular}


While in the case of engineering stream, it was found that 66.66 per cent were visual learners, where teaching through presentations, diagrams and handouts would be most effective. The arts and science stream students preferred both visual and auditory learning styles, 51.43 per cent and 37.14 per cent respectively. The highest percentage $(13.73 \%)$ of kinesthetic learners was found among engineering students.

\section{Relationship Between Learning Styles and Academic Achievement}

Academic achievement is the percentage of marks obtained by the respondent before administering this study. The relationship between learning styles and academic achievement was studied using correlation and one way ANOVA.

Table 2.

Relationship between Learning Styles and Academic Achievement

\begin{tabular}{|l|c|c|c|c|}
\hline \multicolumn{1}{|c|}{ Correlation } & Mean & S.D & r & sig \\
\cline { 1 - 3 } Learning styles & 54.93 & 6.680 & \multirow{2}{*}{0.031 (NS) } & \multirow{2}{*}{0.74} \\
\cline { 1 - 3 } Academic achievement & 75.32 & 7.448 & \\
\hline
\end{tabular}

$\mathrm{NS}=$ Non significant

Table 3.

Students' Mean Scores for different Learning Styles

\begin{tabular}{|c|c|c|c|c|c|c|}
\hline $\begin{array}{l}\text { S1. } \\
\text { No. }\end{array}$ & Learning Style & $\begin{array}{l}\text { Frequ } \\
\text { ency }\end{array}$ & $\begin{array}{c}\text { Mean } \\
\text { percentage } \\
\text { of marks }\end{array}$ & $\begin{array}{l}\text { Standard } \\
\text { deviation }\end{array}$ & $\begin{array}{l}\text { Minimum } \\
\text { marks }\end{array}$ & $\begin{array}{l}\text { Maximum } \\
\text { marks }\end{array}$ \\
\hline 1. & Visual & 59 & 75.02 & 7.66 & 52.00 & 90.00 \\
\hline 2. & Auditory & 36 & 76.14 & 7.69 & 62.00 & 94.00 \\
\hline 3. & Kinesthetic & 9 & 70.73 & 4.26 & 63.25 & 80.00 \\
\hline 4. & Visual+Auditory & 4 & 76.25 & 4.99 & 71.00 & 81.00 \\
\hline 5. & Visual+Kinesthetic & 1 & 80.00 & . & 80.00 & 80.00 \\
\hline 6. & Auditory + Kinesthetic & 1 & 81.00 & . & 81.00 & 81.00 \\
\hline 7. & $\begin{array}{l}\text { Visual+Auditory+ } \\
\text { Kinesthetic }\end{array}$ & 2 & 82.80 & 8.77 & 76.60 & 89.00 \\
\hline & Total & 112 & 75.32 & 7.45 & 52.00 & 94.00 \\
\hline
\end{tabular}

Table 4.

One way ANOVA for Significant Score Differences between Learning Style Groups

\begin{tabular}{|l|c|c|c|c|c|}
\hline & Sum of Squares & df & Mean Square & F & Sig \\
\hline Between Groups & 356.59 & 6 & 59.43 & & \\
Within Groups & 14928.44 & 105 & 142.18 & \multirow{2}{*}{0.418} & 0.866 \\
\hline Total & 15285.03 & 111 & & & \\
\hline
\end{tabular}

According to the findings of one-way ANOVA, existence of possible differences between the means among seven learning styles were not significant as shown in table 04. $F(6,105)=0.418, \quad p>0.05$. 
From Table 2, it could be seen that the mean academic achievement was 75.32 and the mean score obtained for the divergent learning styles was 54.93. The correlation coefficient ' $r$ ' was 0.031 at a significance level of 0.74 . The data indicate that there is no significant association between the learning styles and the academic achievement of students. The one way ANOVA (Table. 3) revealed that, the mean percentage of marks for unimodal learners ranged from 70 to 76 per cent, whereas for bimodal learners it was 80 per cent. Trimodal learners $(82.80 \%)$ obtained the highest mean percentage of marks. From Table 4, it could be seen that none of the learning style groups showed significant statistical association with academic achievement.

The findings of the study reveal that learning styles do not have a significant influence on academic achievement. This is in accordance with earlier findings (Karalliyadda, 2017; Turky \& Almigbal, 2015; Victor, 2011), who concluded that there is no substantial association between learning styles and academic performances.

Though this study could not find possible significant relationship between learning styles and academic achievement, this cannot be generalised, as earlier researches have indicated contrary (Loulwa, 2013). This may be possibly because these learning style models have not completely comprehended the students' learning process. Further studies, are therefore needed to identify other methods to assess learning styles and their relationship with academic achievement.

\section{CONCLUSION}

The results of the study revealed that majority of the students are visual learners, followed by auditory learners. The stream- wise distribution of the students showed that the highest percentage of visual learners was found in engineering stream. A majority of the students were auditory learners in the horticultural and agricultural streams with 62.50 percent and 61.11 percent respectively. Most of the students of agricultural stream were found to be unimodal learners.

The highest percentage (13.73\%) of kinesthetic learners was found among engineering students. Studies on correlation and one way ANOVA did not show any significant association between the learning styles and the academic achievement of students. The mean percentage of marks for unimodal learners ranged from 70 to 76 per cent, whereas for bimodal learners it was 80 per cent. The highest mean percentage of marks was obtained by trimodal learners (82.80\%).

The key to utilizing these results on the undergraduate students' learning styles is to incorporate students' learning styles in the planning and delivery of instruction by the teaching faculty. It is also imperative that the teachers should 
equip the students with knowledge of their own learning styles, so that they make necessary efforts for inducing a change in their learning behaviours, if warranted.

With the students of agricultural and horticultural streams being mostly auditory learners it is essential that teachers incorporate more of discussions, brain storming etc into their teaching repertoire to make their teaching more effective. Trimodal learners had the highest mean percentage of marks, which implies that a combination of learning styles would be more beneficial. Though it was observed that academic achievement was not dependent on learning styles, it would be most appropriate to attempt to cater for all learning styles during lessons to enable the most efficient learning to take place.

\section{REFERENCES}

Barbe, Walter Burke, Swassing, Raymond, H. \& Milone, Michael, N. (1979). Teaching through modality strengths: concepts and practices. Columbus, Ohio: Zaner- Bloser.

Cronbach, L., \& Snow. (1977). Aptitudes and Instructional Methods: A Handbook for Research on Interactions. New York: Irvington.

Felder, R.M. \& Brent, R. (2005). Understanding student differences, Journal of Engineering Education, 94 (1), 57-72.

Jayakumar. N \& M. Surudhi. (2015). Schooling background and academic achievement of agricultural students, Journal of Extension Education, 27(2): 5468- 5475.
Karalliyadda,S.M.C.B. (2017). Learning Style and Academic Performance of First Year Agricultural Undergraduates: A Case in Rajarata University of Sri Lanka, The Journal of Agricultural Sciences 12(1) 34-42.

Keefe, J.W. (1979). Learning Style: An Overview, Reston, Va.: National Association of Secondary School Principals, 1-17

Loulwa, Mohammed, S.A. (2013). Learning style preference of firstyear dental students at King Saud University in Riyadh, Saudi Arabia: Influence of gender and GPA, Journal of Dental Education, 77(10),1371-1378.

Pashler, H., McDaniel, M., Rohrer, D. \& Bjork, R. (2008). Learning Styles: Concepts and Evidence. Psychological Science in the Public Interest, Retrieved from http://www. psychologicalscience.org/index.php/ publications/journals/pspi

Turky, H.,\& Almigbal, T.H. (2015). Relationship between the learning style preferences of medical students and academic achievement, Saudi Medical Journal, 36 (3), 349-355.

Victor, M. (2011). An analysis of some factors affecting student academic performance in an introductory biochemistry course at the University of the West Indies, Caribbean Teaching Scholar, 1(2), 79-92.

http: / /www.swinburne.edu.au/stuserv/ workshops/onlinematerials/Web\%20 Effective\%20study\%20Skills_ files / 1VAK\%20assessment.pdf 